\title{
GERMINAÇÃO E VIGOR DE SEMENTES DE MILHO RECOBERTAS E VIABILIDADE DO INÓCULO DURANTE O ARMAZENAMENTO
}

\author{
Germination and vigor of covered corn seeds and viability of the inoculum during storage
}

\author{
Patrícia Marluci da Conceição ${ }^{1}$, Henrique Duarte Vieira ${ }^{2}$, Roberto Ferreira da Silva ${ }^{3}$, Silvia de Carvalho Campos ${ }^{4}$
}

\begin{abstract}
RESUMO
Conduziu-se este trabalho com o objetivo de avaliar a qualidade fisiológica das sementes recobertas com diferentes misturas e armazenadas, assim como a sobrevivência das células bacterianas no recobrimento destas. Utilizou-se neste estudo a estirpe $H$. seropedicae Z67 BR 11175. O recobrimento das sementes de milho 'UENF 506-8' foi realizado com a mistura de calcário, meio de cultura semi-sólido, água e cimentante. As sementes foram acondicionadas durante três meses, em sacos de papel multifoliado e armazenadas em duas condições: ambiente de laboratório (temperatura média de $26,2{ }^{\circ} \mathrm{C}$ e UR média de $61,5 \%$ ) e câmara BOD. A cada 30 dias de armazenamento, foram efetuadas determinações do teor de água, contagem de bactérias e avaliações da qualidade fisiológica das sementes. O recobrimento das sementes não altera a perda natural da qualidade fisiológica das sementes durante o armazenamento. Dentre as condições de armazenamento estudadas, a mais adequada para a manutenção das sementes foi a temperatura média de 26,4 ${ }^{\circ} \mathrm{C}$ e UR média de $61,5 \%$. As células bacterianas foram observadas nas raízes das plântulas oriundas de sementes revestidas com bactéria, armazenadas por até 60 dias independente da condição de armazenamento.
\end{abstract}

Termos para indexação: Germinação, recobrimento, bactérias diazotróficas, ácidos húmicos.

\begin{abstract}
The aim of this study was to evaluate the physiological quality of stored seeds covered with different mixtures and the period of survival of the bacterial cells in the seed coatings. H. seropedicae Z67 BR 11175 was used in this study. The 'UENF 506-8' corn seeds were coated with a mixture preparation consisting of lime, JNFb semi-solid medium, water and cement. The seeds were conditioned for three months in paper bags and stored under two conditions: laboratory (at a temperature of $26.2{ }^{\circ} \mathrm{C}$ and $61.5 \%$ relative humidity) and BOD chamber. Every 30 days of storage determinations of the water content, counting of bacteria, and evaluations of the physiologic quality of the seeds were performed. The coating of the seeds did not modify the natural loss of physiological quality of the seeds during the storage. Among the storage conditions studied, the most appropriate for the maintenance of the seeds was the $26.2^{\circ} \mathrm{C}$ and $61.5 \%$ of relative humidity. Bacterial cells were detected in the roots of plants originated from coated seeds inoculated with bacterial and stored up to 60 days independently the of storage conditions.
\end{abstract}

Index terms: Germination, coating, diazotrophic bacteria, humic acid.

(Recebido em 22 de abril de 2008 e aprovado em 22 de setembro de 2008)

\section{INTRODUÇÃO}

O aumento do custo dos adubos nitrogenados e a preocupação cada vez maior com possíveis efeitos negativos do excesso de nitrato nos mananciais são fatores que devem ser levados em consideração para o incentivo ao estudo do processo natural de fixação biológica do nitrogênio (FBN) (Cantarella \& Duarte, 2004). Esse processo é realizado por microrganismos chamados diazotróficos (bactérias e cianobactérias fixadoras de nitrogênio).

Para que a fixação biológica seja explorada em seu máximo potencial, é necessário que estirpes eficientes estabeleçam-se nas raízes das plantas. Quando a população microbiana no solo não é grande ou as estirpes não são eficientes, torna-se necessário recorrer a métodos artificiais de introdução de estirpes selecionadas. A prática de inoculação é muito divulgada e adotada, principalmente, em leguminosas (Coelho, 2001).

Em poáceas, as bactérias fixadoras de nitrogênio que colonizam as plantas podem ser agrupadas em três categorias: organismos de rizosfera, que incluem todas as espécies que colonizam a superfície radicular, tais como, Azotobacter paspali e Beijerinckia spp.; endofíticos facultativos, todas as bactérias diazotróficas que podem colonizar a superfície e interior das raízes, representadas basicamente pelas espécies de Azospirillum, exceto A.

\footnotetext{
${ }^{1}$ Engenheira Agrônoma, Mestre em Produção Vegetal - Universidade Estadual do Norte Fluminense Darcy Ribeiro/UENF - Av. Alberto Lamego, 2000 Parque Califórnia - 28013-602 - Campos dos Goytacazes, RJ - patymarluci@yahoo.com.br

Engenheiro Agrônomo, Doutor em Produção Vegetal - Laboratório de Fitotecnia/LFIT - Universidade Estadual do Norte Fluminense Darcy Ribeiro/ UENF - Av. Alberto Lamego, 2000 - Parque Califórnia - 28013-602 - Campos dos Goytacazes, RJ - henrique@uent.br

${ }^{3}$ Engenheiro Agrônomo, Ph.D - Laboratório de Fitotecnia/LFIT - Centro de Ciências e Tecnologias Agropecuárias/CCTA - Universidade Estadual do Norte Fluminense Darcy Ribeiro/UENF - Av. Alberto Lamego, 2000 - Parque Califórnia - 28013-602 - Campos dos Goytacazes, RJ - roberto@uenf.br ${ }^{4}$ Engenheira Agrônoma, Mestre em Produção Vegetal - Universidade Estadual do Norte Fluminense Darcy Ribeiro/UENF - Av. Alberto Lamego, 2000 Parque Califórnia - 28013-602 - Campos dos Goytacazes, RJ - silvinhacarv@yahoo.com.br
} 
halopraeferens; e endofíticos obrigatórios, constituídos, principalmente, pelas espécies isoladas mais recentemente como Gluconacetobacter diazotrophicus, Herbaspirillum spp. e Azoarcus, que são capazes de colonizar o interior das raízes e tecidos aéreos das plantas (Baldani et al., 1997).

A eficiência da produção de inoculantes para poáceas, assim como em leguminosas, depende, entre outros fatores, da manutenção do número mínimo de células viáveis da bactéria no inoculante, desde a sua fabricação até o uso pelo agricultor (Ferreira et al., 2003).

O recobrimento de sementes pode ser uma forma de inoculação das bactérias diazotróficas endofíticas em poáceas, no entanto, não existem pesquisas avaliando o período de sobrevivência das células bacterianas no recobrimento, durante o armazenamento.

Apesar do acentuado incremento no uso de sementes recobertas, verificado nos últimos anos, são poucas as informações que têm sido publicadas sobre a resposta destas sementes durante o período de armazenamento (Mendonça, 2003; Oliveira et al., 2003). Entretanto, acredita-se que os princípios fundamentais para a correta conservação das sementes recobertas são os mesmos reconhecidos para as sementes nuas. Segundo Carvalho \& Nakagawa (2000), as melhores condições para preservação da qualidade de sementes ortodoxas são aquelas que mantêm o embrião em baixa atividade metabólica, em geral, em condições de baixa umidade relativa do ar e baixa temperatura.

A presença de ácidos húmicos ( $\mathrm{AH}$ ) no recobrimento pode aumentar a eficiência da infecção das bactérias nas plantas. Segundo Marques Júnior (2006), os AH estimulam o aumento de raízes laterais e sítios mitóticos, aumentando os pontos de infecção para as bactérias diazotróficas endofíticas.

Neste estudo, objetivou-se avaliar a qualidade fisiológica de sementes recobertas com ácidos húmicos e bactérias diazotróficas armazenadas e o período de sobrevivência das células bacterianas no recobrimento.

\section{MATERIALE MÉTODOS}

As avaliações foram realizadas na Universidade Estadual do Norte Fluminense Darcy Ribeiro (UENF) em Campos dos Goytacazes - RJ. Utilizou-se, neste estudo, a estirpe $H$. seropedicae Z67 Br 11175, isolada de raízes de arroz (Baldani et al., 1986), proveniente da coleção de bactérias diazotróficas da Embrapa Agrobiologia, município de Seropédica, RJ.

Para preparação da bactéria para o recobrimento, uma colônia da estirpe foi inoculada em meio DYGS líquido (Rodrigues Neto et al., 1986), permanecendo sob agitação a $150 \mathrm{rpm}$ por $24 \mathrm{~h}$ a $30^{\circ} \mathrm{C}$. Uma alíquota de $30 \mu \mathrm{L}$ da cultura bacteriana $\left(2 \times 10^{9}\right.$ células por $\left.\mathrm{mL}\right)$ foi transferida para frascos de vidro (volume $12 \mathrm{~mL}$ ) contendo $5 \mathrm{~mL}$ de meio JNFb semisólido (Baldani et al., 1992). Os frascos foram incubados por $72 \mathrm{~h}$ a $30^{\circ} \mathrm{C}$ para a multiplicação bacteriana e formação da película. Em parte dos frascos de vidro, houve adição de $\mathrm{AH}$ isolado de vermicomposto, na concentração de $40 \mathrm{mgL}^{-1}$

O recobrimento das sementes de milho ('UENF 5068 ') foi realizado com a mistura de $70 \%$ de calcário, $10 \%$ de meio de cultura semi-sólido JNFb e $20 \%$ de água destilada. Foi adicionado a essa mistura $2 \%$ de agente cimentante (cola a base de acetato de polivinila). As sementes foram recobertas uma a uma com auxílio de uma pinça e, em seguida, postas a secar ao ar livre, durante um período de 24 horas. Em seguida, as sementes foram acondicionadas em sacos de papel multifoliado e armazenadas por três meses em dois ambientes: ambiente de laboratório, no qual a temperatura e umidade relativa (UR) foram monitoradas a cada três dias com termohigrógrafo, e câmara BOD a $20^{\circ} \mathrm{C}$ e $70 \pm 5 \%$ UR.

Os tratamentos avaliados foram: T1: sementes nuas (controle); T2: sementes recobertas com meio de cultura JNFb semi-sólido; T3: sementes recobertas com meio de cultura JNFb semi-sólido + AH; T4: sementes recobertas com meio de cultura JNFb semi-sólido + bactérias e T5: sementes recobertas com meio de cultura JNFb semi-sólido + $\mathrm{AH}+$ bactérias.

No início e a cada 30 dias de armazenamento, foram realizadas as seguintes avaliações: teor de água das sementes - expresso em base úmida determinado pelo método de estufa a $105 \pm 3{ }^{\circ} \mathrm{C}$ por 24 horas, utilizando duas amostras de quatro a cinco gramas de sementes por tratamento. O teste de germinação (TG) e a primeira contagem do TG foram realizados de acordo com as recomendações apresentadas nas Regras para Análises de Sementes (Brasil, 1992), com modificações, utilizando quatro repetições de 25 sementes por tratamento; primeira contagem do TG - realizada conforme metodologia prescrita para o TG, sendo o resultado expresso pela porcentagem das plântulas normais avaliadas no quarto dia após o início do teste; teste de frio sem solo - quatro repetições de 25 sementes por tratamento foram distribuídas em papel germiteste umedecido com água destilada equivalente a 2,5 vezes o peso do papel. Após a semeadura, os rolos foram colocados no interior de sacos plásticos e estes foram mantidos em câmara tipo BOD regulado a $10^{\circ} \mathrm{C}$, durante sete dias. Em seguida, os rolos no interior dos sacos plásticos foram transferidos para um germinador regulado à temperatura alternada de $20-30{ }^{\circ} \mathrm{C}$, onde permaneceram por mais sete dias. A avaliação da germinação foi realizada de acordo com as prescrições das Regras para Análise de Sementes (Brasil, 1992); células bactérias presentes no tecido radicular - foi estimado pela 
multiplicação de bactérias fixadoras de nitrogênio em meio de cultura JNFb semi-sólido. A combinação entre presença e/ou ausência de formação de película observada para três repetições por diluição foi utilizada para determinar o NMP na tabela de McCrady (Döbereiner et al., 1995).

$\mathrm{O}$ experimento foi instalado seguindo o delineamento inteiramente casualizado. Utilizou-se um esquema fatorial $5 \times 2 \times 4$, correspondente a cinco tratamentos, dois ambientes de armazenamento e quatro períodos de armazenamento. Os dados foram submetidos à análise de variância (F a 5\% de probabilidade). Os graus de liberdade dos fatores isolados, assim como da interação entre os fatores foram desdobrados via teste de comparação de médias (fatores qualitativos) e análise de regressão (fatores quantitativos). Os resultados da contagem de bactérias pela técnica do NMP para os tratamentos sementes nuas, meio e meio $+\mathrm{AH}$ foram apresentados por meio das médias obtidas durante o armazenamento das sementes, pois nenhum modelo de regressão descreveu o comportamento dos dados.

\section{RESULTADOS E DISCUSSÃO}

Na Figura 1, encontra-se a variação da temperatura e UR do ar (média, máxima e mínima) do ambiente de laboratório, durante o período de armazenamento. A temperatura média no período de armazenamento foi de $26,4^{\circ} \mathrm{C}$, com média máxima de $27,2^{\circ} \mathrm{C}$ e média mínima de $25,2^{\circ} \mathrm{C}$. Observa-se que a temperatura do laboratório foi, durante todo o período de armazenamento, superior à temperatura da câmara BOD $\left(20^{\circ} \mathrm{C}\right)$. A UR média do ar no laboratório foi de $61,5 \%$, com média máxima de $65,7 \%$ e média mínima de 54,1\%. A umidade relativa do ar média no laboratório foi inferior a UR da câmara BOD (70 $\pm 5 \%)$.

Durante o armazenamento, foi possível verificar que as sementes armazenadas no laboratório, inclusive o controle, mostraram-se com valores de teor de água mais baixos em relação às sementes armazenadas em câmara BOD, indicando que as embalagens permitiram troca de umidade entre as sementes e o ambiente. Neste caso, a UR mais baixa e a maior temperatura no laboratório propiciaram maior perda de água destas sementes (Tabela 1).

No início do armazenamento (tempo 0), as sementes recobertas continham maior teor de água do que as nuas. $\mathrm{Na}$ mistura do recobrimento é adicionada água e com isso há um aumento do teor de água nas sementes, logo após o recobrimento. No entanto, durante o armazenamento, as sementes recobertas mostraram valores de teor de água consideravelmente mais baixos do que os verificados para sementes nuas (Tabela 1), indicando que a água presente no recobrimento é perdida mais rapidamente do que a água das sementes, diminuindo o teor de água das sementes recobertas.

Para comprovar que o baixo teor de água nas sementes recobertas é consequência da perda de água pelo recobrimento, foi avaliado o teor de água das sementes nuas, sementes recobertas, sementes descobertas (o material do recobrimento foi retirado) e do recobrimento, todos armazenados por 90 dias em laboratório (Tabela 2).

Os dados mostraram que as sementes descobertas possuem um teor de água semelhante ao das sementes nuas, enquanto as sementes recobertas contêm um menor valor. O recobrimento propiciou um teor de água extremamente baixo, atribuindo-se ao mesmo o componente responsável pelo menor teor de água das sementes recobertas. Portanto, pode-se considerar que o calcário constitui um recobrimento com baixa retenção de umidade, o que também foi observado por Silva \& Nakagawa (1998).

Analisando os dados da primeira contagem do TG e do teste de germinação (Tabela 3), constatou-se efeito significativo do ambiente de armazenamento, sendo os valores obtidos para as sementes armazenadas no laboratório superiores aos obtidos para sementes armazenadas em câmara BOD. Possivelmente, a maior umidade relativa no interior da câmara BOD causou maior deterioração das sementes, sendo este ambiente menos eficiente na preservação do vigor das sementes.

A maior umidade relativa no interior da câmara BOD, em relação à umidade relativa média do laboratório, e a embalagem permeável onde estavam acondicionadas as sementes provocaram maior deterioração das sementes como relatam Freitas et al. (1992).

As curvas da Figura 2, mostram que a germinação das sementes nuas foi mais lenta, quando comparadas às sementes recobertas, independente da 'mistura' aplicada. Possivelmente, o recobrimento das sementes, ao ser umedecido, não formou uma barreira física à germinação das sementes. Além disso, o pH menos ácido em torno das sementes recobertas, pela presença do calcário, pode ter beneficiado a germinação.

Não houve diferença significativa entre os tratamentos durante o teste de germinação. Na Figura 3, podemos observar uma redução significativa na germinação das sementes ao longo do armazenamento. O decréscimo observado na porcentagem de germinação das sementes nuas ou recobertas pode ser atribuído ao processo natural de deterioração das sementes. Esses resultados estão de acordo com Oliveira et al. (2003), os quais também verificaram redução da qualidade das sementes nuas e recobertas de pimentão ao longo do armazenamento quando estas foram armazenadas em embalagem permeável. 

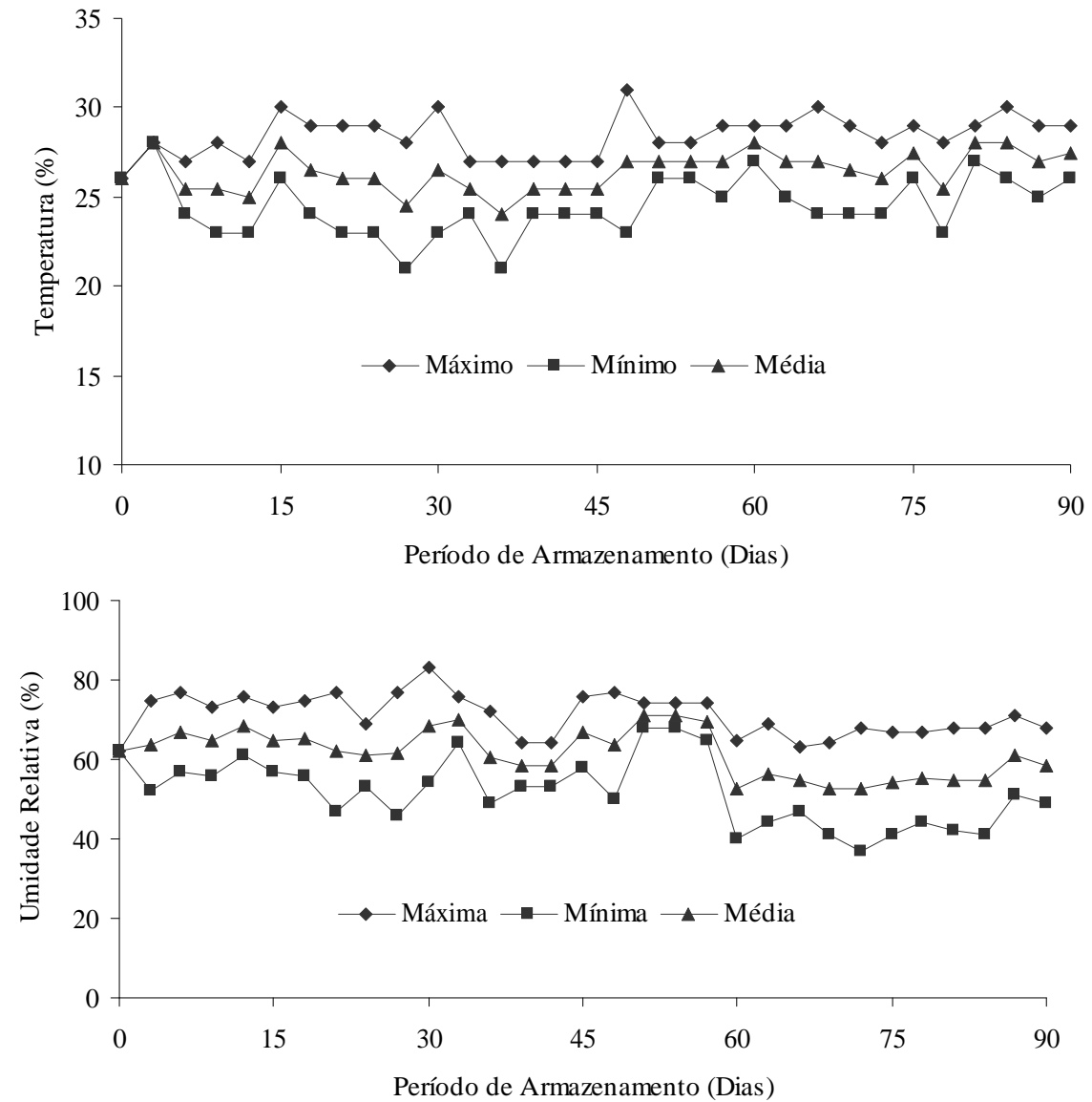

Figura 1 - Variação da temperatura $\left({ }^{\circ} \mathrm{C}\right)$ e da umidade relativa $(\%)$ máxima, mínima e média no laboratório durante o armazenamento das sementes de milho 'UENF 506-8'.

Tabela 1 - Teor de água (\%) de sementes de milho ('UENF 506-8') nuas e recobertas determinado durante o armazenamento.

\begin{tabular}{llcccc}
\hline \multirow{2}{*}{$\begin{array}{c}\text { Condições de } \\
\text { armazenamento }\end{array}$} & \multicolumn{1}{c}{ Tratamentos } & \multicolumn{3}{c}{ Período de Armazenamento (Dias) $^{1}$} \\
\cline { 3 - 5 } & Sementes Nuas (Controle) & 11,12 & 11,95 & 12,40 & 12,34 \\
& Meio & 14,29 & 8,85 & 7,66 & 8,27 \\
\multirow{3}{*}{ Câmara BOD } & Meio + AH & 12,61 & 7,53 & 8,70 & 8,54 \\
& Meio + Bactérias & 16,20 & 7,38 & 9,23 & 7,99 \\
& Meio + AH + Bactérias & 16,35 & 8,44 & 7,53 & 7,88 \\
\hline \multirow{5}{*}{ Laboratório } & 11,12 & 10,04 & 10,39 & 8,95 \\
& Sementes Nuas (Controle) & 14,29 & 7,04 & 7,27 & 6,39 \\
& Meio & 12,61 & 7,23 & 8,92 & 5,65 \\
& Meio + AH & 16,20 & 6,00 & 7,77 & 6,06 \\
& Meio + Bactérias & 16,35 & 6,16 & 6,70 & 4,82 \\
\hline
\end{tabular}

Ciênc. agrotec., Lavras, v. 33, n. 3, p. 765-772, maio/jun., 2009 
Tabela 2 - Teor de água (\%) em sementes nuas, recobertas ou descobertas de milho 'UENF 506-8', após 90 dias de armazenamento em condições não controladas de temperatura e umidade (laboratório).

\begin{tabular}{lc}
\hline \multicolumn{1}{c}{ Tratamentos } & Teor de água $(\%)$ \\
\hline Sementes nuas & 9,95 \\
Sementes recobertas & 6,03 \\
Sementes descobertas & 9,93 \\
recobrimento & 0,47 \\
\hline
\end{tabular}

Tabela 3 - Influência do local e condição de armazenamento sobre a porcentagem de germinação e a primeira contagem do TG de sementes de milho 'UENF 506-8'.

\begin{tabular}{lcc}
\hline \multicolumn{1}{c}{ Local } & $\begin{array}{c}\text { Primeira } \\
\text { contagem do } \\
\text { TG }(\%)\end{array}$ & $\begin{array}{c}\text { Germinação } \\
(\%)\end{array}$ \\
\hline Laboratório & $83,84 \mathrm{a}$ & $98,0 \mathrm{a}$ \\
Câmara BOD & $80,74 \mathrm{~b}$ & $96,3 \mathrm{~b}$ \\
\hline
\end{tabular}

As médias dentro de cada coluna seguidas da mesma letra não diferem entre si pelo teste de Tukey, a $5 \%$ de probabilidade.
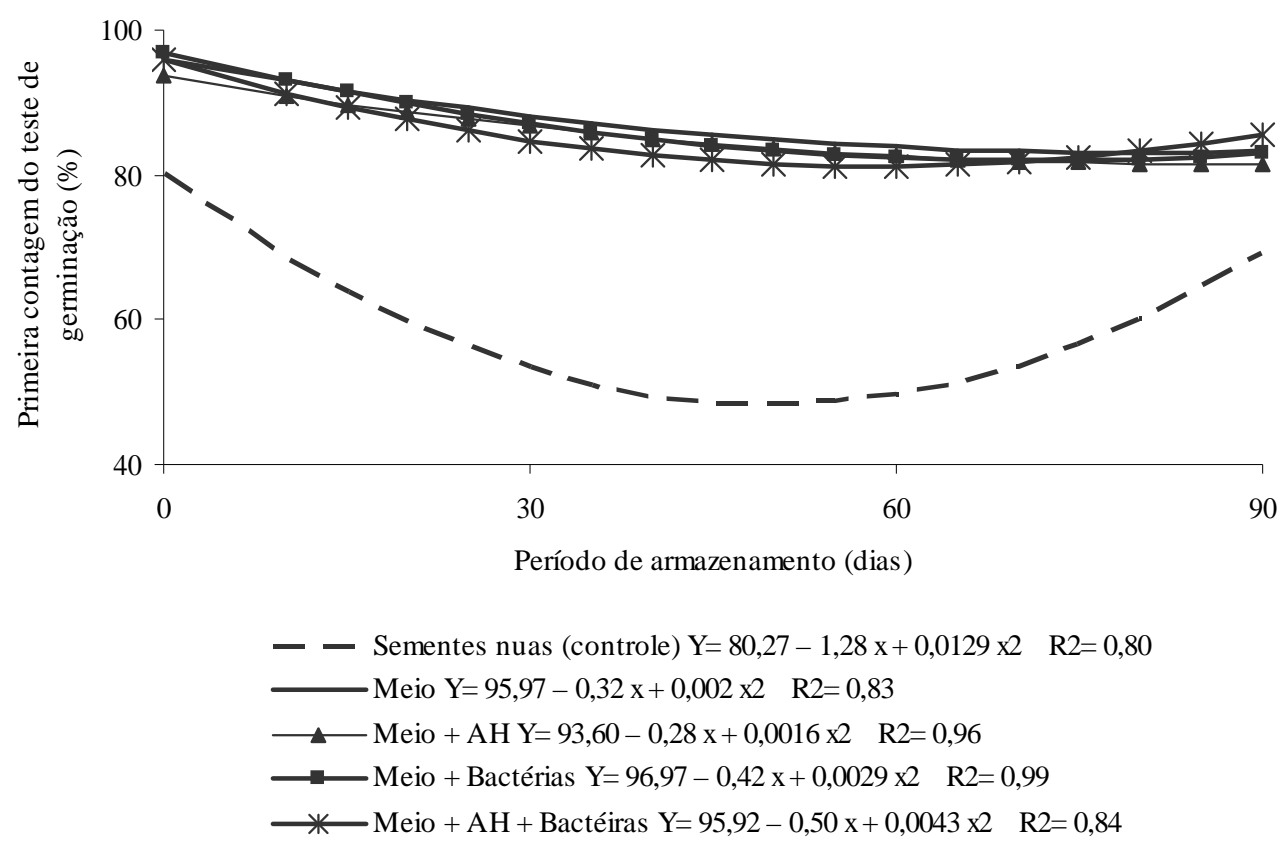

Figura 2 - Influência do tempo de armazenamento na primeira contagem do TG de sementes de milho 'UENF 506-8' nuas ou recobertas.

$\mathrm{Na}$ avaliação do teste de frio não foi observada diferença significativa entre as sementes nuas e recobertas, independente das condições de armazenamento (Tabela 4). Esses resultados estão de acordo com Coraspe et al. (1993), que não observaram diferença significativa na avaliação do teste de frio entre sementes nuas e recobertas de alface. No entanto, ao longo do armazenamento observou-se redução, significativa, no vigor das sementes avaliadas pelo teste frio (Figura 4).

A adição das bactérias e dos $\mathrm{AH}$ não influenciou negativamente a qualidade fisiológica das sementes avaliadas pela primeira contagem do TG, teste de germinação e teste de frio (Figura 2, 3 e Tabela 4).
Na avaliação do número de bactérias não foi observado efeito do ambiente de armazenamento. Na Figura 5, encontramse os resultados da avaliação da multiplicação bacteriana resultante da avaliação por meio da técnica do NMP. A presença de bactérias nos tratamentos com sementes nuas, meio e meio + AH, no tempo 0 (zero), provavelmente, foi consequência da contaminação por bactérias diazotróficas nativas presentes nas sementes. A detecção de bactérias em plantas onde não houve a inoculação de bactérias nas análises de NMP é comum, visto que os meios utilizados durante a técnica e para o recobrimento das sementes são semi-seletivos (Canuto, 2003). No entanto, aos 30, 60 e 90 dias não foi detectada a presença das bactérias pela técnica do NMP nestes tratamentos. 


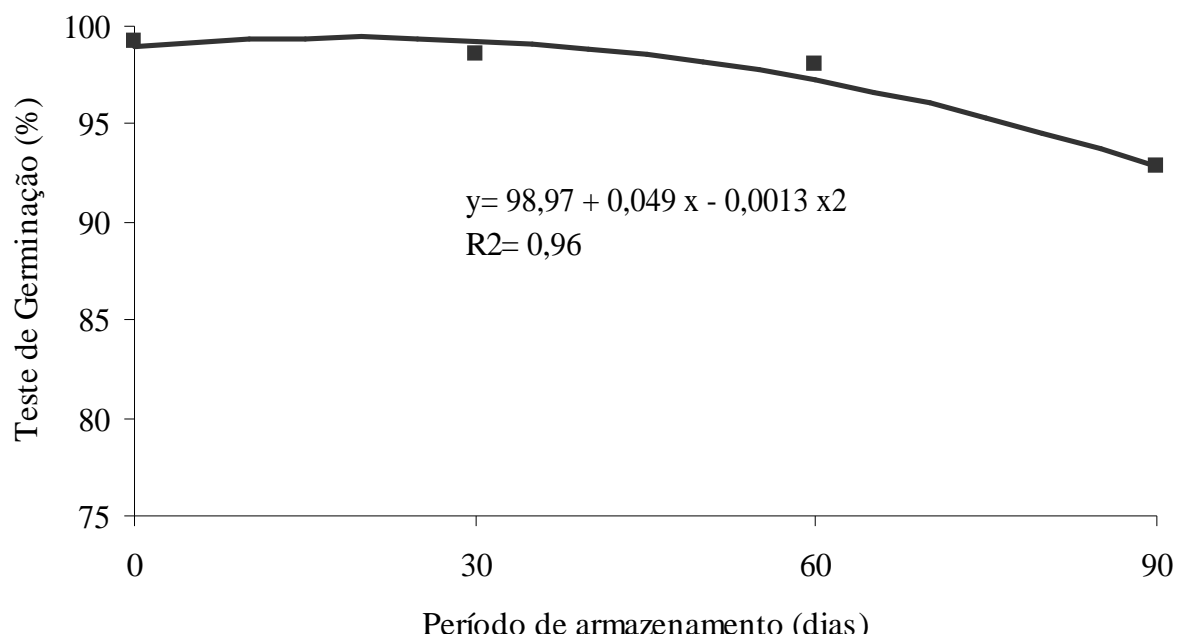

Figura 3 - Valores médios de germinação de sementes nuas e recobertas de milho 'UENF 506-8' durante o armazenamento.

Tabela 4 - Teste frio de sementes de milho 'UENF 506-8' nuas e recobertas.

\begin{tabular}{lc}
\hline \multicolumn{1}{c}{ Tratamentos } & Médias \\
\hline Controle & $96,4 \mathrm{a}$ \\
Meio & $96,4 \mathrm{a}$ \\
Meio + AH & $96,6 \mathrm{a}$ \\
Meio + Bactéria & $94,2 \mathrm{a}$ \\
Meio + AH + Bact. & $94,1 \mathrm{a}$ \\
\hline
\end{tabular}

As médias dentro da coluna seguidas da mesma letra não diferem entre si pelo teste de Tukey, a $5 \%$ de probabilidade

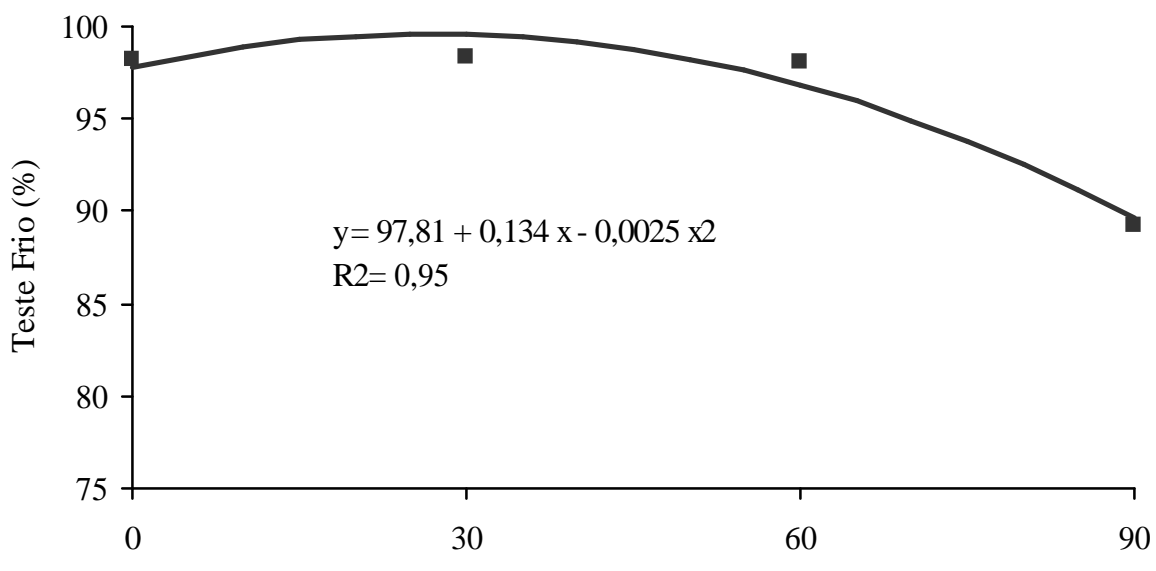

Período de armazenamento (dias)

Figura 4 - Valores médios do teste de frio de sementes nuas e recobertas de milho 'UENF 506-8' durante o armazenamento. 


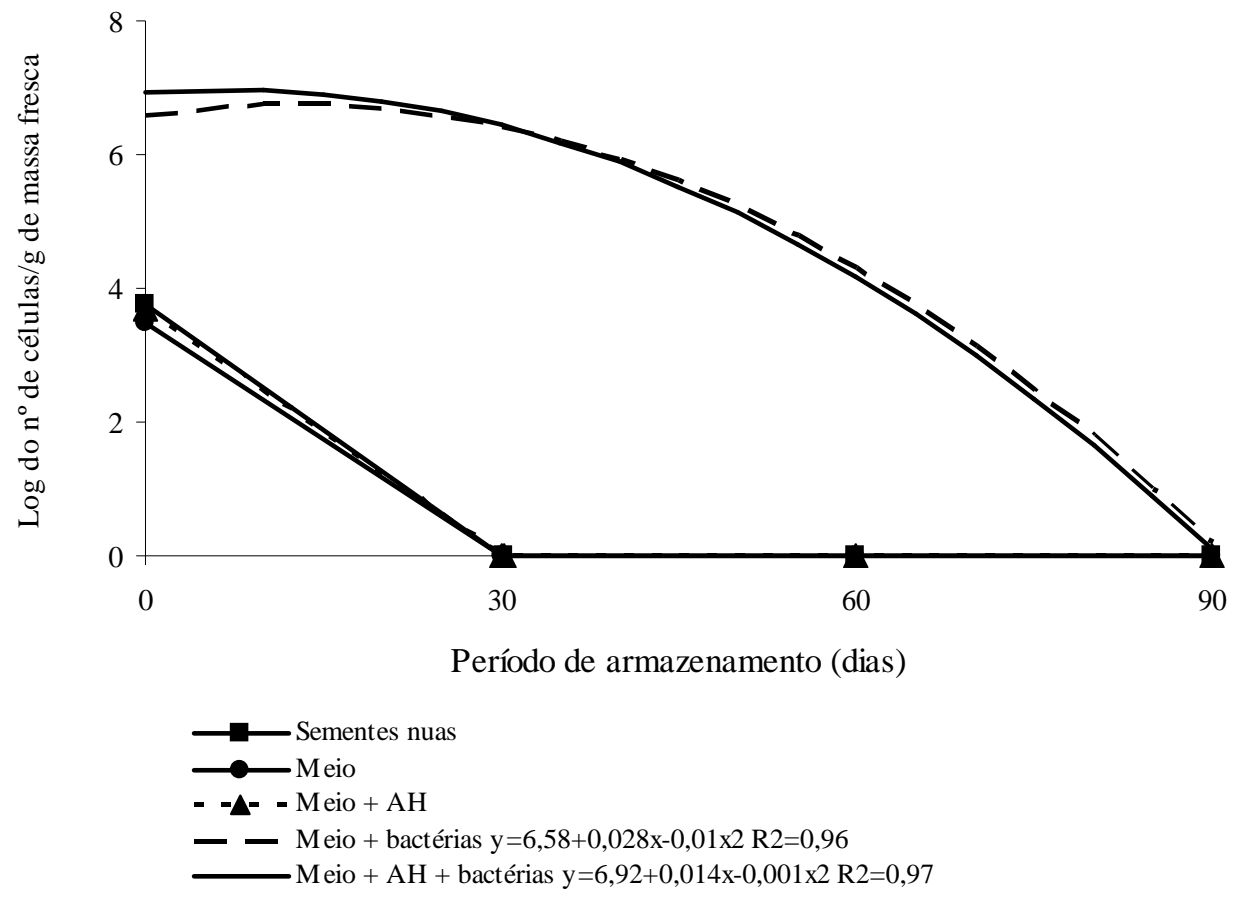

Figura 5 - Número de bactérias diazotróficas (expresso em log do número de células por grama de tecido fresco) em raízes de plântulas de milho 'UENF 506-8' oriundas de sementes nuas e recobertas.

Os tratamentos meio+bactérias e meio+bactérias+AH, no tempo 0 , mostraram um número superior de bactérias em relação aos demais tratamentos (Figura 5), evidenciando que a inoculação das bactérias pelo recobrimento de sementes foi eficiente.

Nos tratamentos onde foi realizada a inoculação de bactérias foi detectada a presença das células bacterianas nas raízes das plântulas oriundas de sementes armazenadas por até 60 dias, evidenciando que a técnica do recobrimento permite a sobrevivência das células bacterianas por um período de tempo. Assim, as sementes inoculadas pela técnica do recobrimento não precisam ser semeadas logo após o recobrimento, podendo ser armazenadas por um período de até 60 dias.

A presença dos $\mathrm{AH}$ no recobrimento não alterou o tempo de sobrevivência das bactérias no recobrimento. Esses dados corroboram com Marques Júnior (2006), o qual avaliou diferentes concentrações de AH e verificou um mesmo padrão de sobrevivência das bactérias em relação ao controle (sem a presença de $\mathrm{AH})$.

O recobrimento de sementes mostrou eficácia como inoculante de bactérias diazotróficas endofíticas da espécie Herbaspirillum seropedicae (Z67), preservando a viabilidade das células bacterianas por um período de até 60 dias sem que houvesse perda da qualidade.

\section{CONCLUSÕES}

O recobrimento não prejudica a qualidade fisiológica das sementes durante o armazenamento.

Dentre as condições de armazenamento estudadas, a mais adequada para a preservação da qualidade fisiológica das sementes foi o laboratório $\left(26,2^{\circ} \mathrm{C}\right.$ de temperatura média e UR média de 61,5\%).

Nos tratamentos onde foi realizada a inoculação de bactérias pelo recobrimento de sementes foi detectada a presença das células bacterianas nas raízes das plântulas oriundas de sementes armazenadas por até 60 dias.

A presença dos AH não altera a sobrevivência das células bacterianas no recobrimento das sementes.

\section{REFERÊNCIAS BIBLIOGRÁFICAS}

\section{BALDANI, V.L.; BALDANI, J.I.; OLIVARES, F.L.;} DÖBEREINER, J. Identification and ecology of Herbaspirillum seropedicae and the closely related Pseudomonas rubrisubalbicans. Symbiosis, Revavot, v.13, p.65-73, 1992. 
BALDANI, J.I.; BALDANI, V.L.D.; SELDIN, L.; DÖBEREINER, J. Characterization of Herbaspirillum seropedicae gen. nov., sp. nov., a root-associated nitrogenfixing bacterium. International Journal of Systematic Bacteriology, Baltimore, v.36, n.1, p.86-93, 1986.

BALDANI, J.I.; CARUSO, L.V.; BALDANI, V.L.D.; GOI, S.R.; DOBEREINER, J. Recent advances in BNF with non-legume plants. Soil Biology and Biochemistry, Great Britain, v.29, p.911-922, 1997.

BRASIL. Ministério da Agricultura e Reforma Agrária. Regras para análise de sementes. Brasília, DF: SNDA/ DNDV/CLAV, 1992. 365p.

CANTARELLA, H.; DUARTE, A.P. Manejo da fertilidade do solo para a cultura do milho. In: GALVÃO, J.C.C.; MIRANDA, G.V. (Eds.). Tecnologias de produção do milho. Viçosa, MG: UFV, 2004. p.139-182.

CANUTO, E.L. Seleção de bactérias diazotróficas endofíticas para uso com insumo biológico em plantas de cana-de-açúcar oriundas de sementes. 2003. 72p. Dissertação (Mestrado em Agronomia)-Universidade Federal Rural do Rio de Janeiro, Seropédica, 2003.

CARVALHO, N.M.; NAKAGAWA, J. Vigor de sementes. In: _. Sementes: ciência, tecnologia e produção. Jaboticabal: Funep, 2000. p.224-242.

COELHO, M.A.O. Atividade da nitrato redutase, composição mineral e caracteres da planta de trigo associados à aplicação de molibdênio, à peletização e à inoculação das sementes com Azospirillum brasilense. 2001. 149p. Tese (Doutorado em Fitotecnia)-

Universidade Federal de Viçosa, Viçosa, MG, 2001.

CORASPE, H.M.; IDIARTE, G.; MINAMI, K. Avaliação do efeito da peletização sobre o vigor de sementes de alface (Lactuca sativa L.). Scientia Agrícola, Piracicaba, v.50, n.3, p.349-354, 1993.
DÖBEREINER, J.; BALDANI, V.L.D.; BALDANI, J.I. Como isolar e identificar bactérias diazotróficas de plantas não-leguminosas. Brasília, DF: Embrapa-SPI; Itaguaí: Embrapa-CNPAB, 1995. 60p.

FERREIRA, J.S.; SABINO, D.C.C.; GUIMARÃES, S.L.; BALDANI, J.I.; BALDANI, V.L.D. Seleção de veículos para o preparo de inoculante com bactérias diazotróficas para arroz inundado. Agronomia, Seropédica, v.37, n.2, p.6-12, 2003.

FREITAS, G.B.; SILVA, R.F.; ARAÚJO, E.F. Influência da condição de armazenamento na qualidade de sementes de milho. Revista Brasileira de Armazenamento, Viçosa, v.17, n.1, p.21-26, 1992.

MARQUES JÚNIOR, R.B. Potencial do uso combinado de substâncias húmicas e bactérias diazotróficas endofíticas para bioestimulação de plantas. 2006. 88p. Dissertação (Mestrado em Produção Vegetal)Universidade Estadual do Norte Fluminense Darcy Ribeiro, Campos dos Goytacazes, 2006.

MENDONÇA, E.A.F. Revestimento de sementes de milho superdoce. 2003. 63p. Tese (Doutorado em Agronomia)-Universidade Estadual Paulista, Jaboticabal, 2003.

OLIVEIRA, J.A.; PEREIRA, C.E.; GUIMARÃES, R.M.; VIEIRA, A.R.; SILVA, J.B.C. Desempenho de sementes de pimentão revestidas com diferentes materiais. Revista Brasileira de Sementes, Brasília, v.25, n.2, p.36-47, 2003.

\section{RODRIGUES NETO, J.; MALAVOLTA JUNIOR, V.A.;} VICTOR, O. Meio simples para o isolamento e cultivo de Xanthomonas campestris pv. citri Tipo B. Suma Phytopathologica, Piracicaba, v.12, p.16, 1986.

SILVA, J.B.C.; NAKAGAWA, J. Confecção e avaliação de péletes de sementes de alface. Horticultura Brasileira, Brasília, v.16, n.2, p.151-158, 1998. 